International Journal of Biology, Pharmaey and Allied Sciences (IJBPAS)

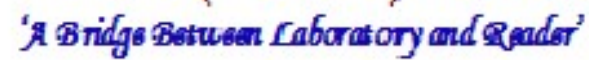

WwW.ijbpas.com

\title{
COVERAGE OF SEPTEMBER 11 ATTACKS: A QUALITATIVE ANALYSIS OF PAKISTANI AND THE BRITISH NEWSPAPERS
}

\author{
SAFDAR A, ALI S* AND BHUTTA MM \\ Department of Communication Studies, Bahauddin Zakariya University Multan, Pakistan \\ *Corresponding aurhor: shahzadmasscomm@bzu.edu.pk
}

Received $7^{\text {th }}$ Nov. 2017; Revised $5^{\text {th }}$ Dec. 2017; Accepted $2^{\text {nd }}$ January 2018; Available online $1^{\text {st }}$ April 2018

\section{ABSTRACT}

The 9/11 attacks had catastrophic impact on the United States. In response to 9/11 attacks America started war against terrorism. These attacks got immense coverage from all over the world media. However, the present study probes how 9/11 attacks on the twin towers were framed by the Pakistani and the British press. Although there is enough literature found relating to war on terror but there is lack of studies which adopted qualitative approach. Moreover, there is very limited studies found which explored Pakistani media perspective regarding 9/11 attacks. The present study explored the editorials from the British newspapers (The Guardian and The Independent) and the Pakistani newspapers (The Dawn, The Nation) from September 12, 2001 to November 12, 2001. The comparative analysis of Pakistani and British press coverage revealed that Pakistani press was dominated by critical themes against America whereas British press stressed on responsible approach by the British government to deal with the crisis.

Keywords: Framing, 9/11 attacks, British press, Pakistani press, thematic analysis \section{INTRODUCTION}

The September 11 attacks have had a substantial impact on the history of United States since the war of 1812 or Japanese strike on Pearl Harbour in 1941 [1] which consequently, led the 'war on terror' later on. The media provided unprecedented coverage to the incident by reporting spectacular images, prominent personalities and human tragedy [2]. Within, a limited time span the news channels were loaded with the stories of terrorist attacks. During the initial phase the audience was more focused on television screens for getting breaking news coverage but later on, 
people wanted to know detailed information .So newspapers became the essential source of reporting on the 9/11 attacks and the war on terror [3, 4]. However, this study aimed to explore the coverage on ' $9 / 11$ attacks' in the context of Pakistani and British press. It sought to investigate how Pakistani and British press framed the coverage of the attacks and what themes were presented by the press. For this reason, the study conducted the comparative analysis of Pakistani and British newspapers editorials regarding the coverage of 9/11 attacks.

The tragedy took place in US when the terrorists on September 11, 2001 crashed four hijacked planes. Two planes smashed into World Trade Centre in New York City, the third plane into Pentagon and the fourth plane into the ground in Pennsylvania. It killed nearly 3000 passengers and damaged more than 30 million square feet area in Lower Manhattan [5] The attacks also impacted American economy by reducing US real GDP growth rate to $0.5 \%$ and increasing unemployment rates to $0.11 \%$ in 2001 [6]. September 11 attacks which occurred in America had been covered by the entire world media. However from its beginning, the media narrowly focused on high profile leader's statements and particularly portrayed President Bush as "facing his greatest test" [7]. Hence, the next morning, the newspapers like New
York Post and The Daily News carried the following headlines; "Act of War" and "It's War" [7]. Under these circumstances, the Bush administration immediately framed these attacks as 'act of war' but within few hours this framing was replaced by "war on terror" [8]. Consequently, this redefined "American foreign policy and its national security strategy" [9]. As President Bush, he by himself declared that the attacks were "more than acts of terror, they were acts of war" [10]. There were many studies have been conducted regarding the framing of 9/11 attacks. The researcher worked on framing of editorials cartoons, news stories, articles, stories of electronic media from the media of different countries. However, the present study would focus on the editorials of Pakistani and British press regarding 9/11 attacks. Because of the editorials had depicted the policy of the news organization. The study would contribute what was the stand point of Pakistani and British press regarding 9/11 attacks.

\section{Framing}

The present study employed the framing theory as the theoretical framework of the research. The study would explore in which perspective 9/11 attacks were framed by the Pakistani and the British press. As the media framing was the theory which described how news content was presented to the readers and how it affected them. 
Gamson and Modigliani argued that media framing was a process through which readers understood the meaning and made their public opinion [11]. It was media that develop and crystallize the meaning for public discourse. Morover, Cissel commented that framing was a tool which was used by the media and the politicians to promote their desired agenda to the minds of the public [12]. Similarly, Tuchman emphasised that mass media set frame of reference accordingly the readers interpret and understood the public issues [13]. Otherwise, Iyengar made his claim that framing theory reflected slight modifications in the presentation of any issue or problem. Eventually, it enhanced the probability that receivers would perceive the information in the perspective of framed strategy [14]. The term frame was mostly referred to as "topic" but Reese regarded it as "organizing" and "structuring"' work [15]. In like manner, de Vreese concluded that frame underlined the prominent aspects of the issue [16]. In fact, frames categorized the world for the journalists who reported them and the audiences who trusted these reports [17]. Nelson and Boynton argued that frames affected public thought by emphasizing particular principles and information, and portrayed them as an issue of significant value whereas if they appeared in a different frame, that frame might depict the reality alternatively [18]. Kinder and Sanders have said that frames were often entrenched in political discussion, this was quite identical to the idea of media frames and the individual frames that depicted the "internal structures of the mind" [19]. Entman mentioned the difference between individual and media frames, explaining the individual frame as "informationprocessing schemata" of individuals and media frames as "attributes of the news itself" [20]. In fact, news frame "creates a structure on which other elements are built', [21].

Bateson stated that frames demarcated "a class or set of messages (or meaningful actions)" [22], accordingly, people understood and estimated the social reality in framed communication. As Reese put it: "frames are organizing principles that are socially shared and persistent over time, that work symbolically to meaningfully structure the social world" [23]. The above discussion could be concluded as the media frames shaped the news story and provided direction to it. Accordingly, the reader or viewer perceived the news story. Similarly, the present study investigated in which manner, the newspapers of Pakistan and Britain framed the incident of 9/11 attacks and what themes got prominence.

\section{Coverage of 9/11 attacks}

The previous literature explored the framing of 9/11 attacks. It was noted that 
during the initial hours of $9 / 11$ attacks the American news channels $(\mathrm{CNN}, \mathrm{ABC}$, NBC, CBS) gave extraordinary coverage. Additionally, their reporters assumed the role of experts and social commentators and used anonymous sources, reported rumours and even included personal references [24]. After September 11 attacks, the US media incorporated the themes of public mobilization through patriotic and war expressions, the criticism on offenders, extraordinary support to President Bush, inclusion of contradictory arguments, uncritical approval of 'official' point of view and the adoption of censorship policies [25]. The media facilitated the government projecting its military intentions in Afghanistan and later in Iraq which successfully persuaded public opinion in favour of US government [26, 27]. According to Schudson when the country was exposed to tragedy, public danger or security crisis, US journalists most often willingly avoided reporting from a neutral perspective [28]. As 9/11 happened, it was difficult for the media to pursue an objective stand point. The role of US journalists was as just as the disseminators of news [29]. Similarly, Haes conducted a comparative study about the coverage of September 11 attacks by US and German news media. He observed that both countries equally gave huge coverage to the terrorist attacks but US media was more inclined towards patriotic evaluation of the incident. Conversely German media underlined the need of international collaboration for tackling the threats of terrorism [30].

Another aspect the researchers had found that in the coverage of international events, journalists tend to localize the event in the context of one's country. For example, Clausen studied the coverage of $9 / 11$ incident by various journalists around the globe. She found that the journalists in different countries played up different elements in their reporting mostly to comply with their cultural frame work. Correspondingly the Western media frequently under reported the antiwar protests and civilian casualties in war on terror [31]. Gao and Liang noted that September 11 attacks received immense coverage by the Chinese media. It reported about consequences of $9 / 11$ on the US, world stock markets, airlines, tourist industries and American economy. While the reporting about Afghanistan war 2001, Chinese newspapers did not support the war rather it stressed upon International organizations and international laws to draw a framework for tackling terrorism [32]. From British press it was noted that the coverage of $9 / 11$ attacks was the big story in British media at that time but the stance of the coverage was not significantly different from the coverage of US media. 
British media borrowed numerous justifications and assumptions from American journalists. In Britain also, 9/11 attacks were portrayed as an "act of war" rather than just an act of terrorism. BBC news adopted the frame of "Attack on America" [33]. The day following the September 11 attacks, nearly all British newspapers published news about the demolished towers with offending gesture. Greensdale notes that the most distinguished feature of British news coverage was the depiction of US 'as one of us' [34]. The Times immediately focused on the images of crashed planes into World Trade Centre, and many other horrific sights. Also, The Times published information regarding private life of Osama Bin Laden showing his son's wedding and Al-Qaeda training camps. Bin Laden was shown as a big threat for civilized world that required action against both him and his supporters [35].

The September 11 attacks were a big event for Pakistani media. Previously, the press was more concerned about domestic, political and social issues but now it had to cover an international conflict at its doorstep. Pakistani news channels and newspapers gave extensive coverage to the incident of $9 / 11$ and thereafter the campaign against terrorism. The statements of Pakistan's government in the national press got more credence than the coverage of US, NATO, Taliban and Afghanistan; and in respect to the framing of war, the Pakistani media did not show favourable impressions towards the US policies against terrorism [36]. The previous literature was explored on the coverage of 9/11 attacks. It was noted that mostly the studies were conducted on the Western media. There were limited studies conducted from Eastern perspective. To fill this gap, the present study would analyse the coverage of 9/11 attacks from Pakistani perspective. Pakistan had immense importance in this perspective because it facilitated war on terror and provided support to the United States. Consequently, it faced threats from Taliban for supporting the United States and tolerated terrorism in response to America actions. The present study explored how Pakistani press looked at the incident and made its comparison with the Britain that was US's ally in the war on terror. The following research questions were made:

R Q:1 How 9/11 attacks were framed by the Pakistani and the British newspapers?

R Q:2 What themes were used to portray 9/11 attacks by the Pakistani and British press?

\section{METHOD}

This study employed qualitative design because this design had holistic approach and descriptive in its nature. This provided an opportunity to the researcher to build a 
complex and holistic picture, analyzes words, reports, information and conducts research in a natural setting [37]. In this research, the qualitative approach analyzed the coverage of 9/11 attacks in British and Pakistani newspaper editorials. It examined the whole text and information in the editorials.For analysing the text of newpaper editorials, the study employed the technique of thematic analysis. Thematic analysis was one of the qualitative techniques that was mostly employed by the researchers. It identified 'what' and 'how' themes take place into text [38] through "careful reading and rereading of the data" [39]. Thematic analysis was utilized to analyze classifications and patterns within data. It described data with rich detail and interpretation [40]. Thematic analysis was further assisted by computerassisted programs that facilitate the data analysis process such as Atlas-ti, Nudist or NVivo. Thus, computer software programmes facilitated the coding process of thematic analysis but it was only the first step. The next step was data interpretation that was quite essential that explained the coded data in the relevant context.

\section{Population for the Study}

For this study two British newspapers namely the Guardianand the Independentand two Pakistani newspapers the dawnand the nationwere selected. Newspapers were retrieved from the Lexis
Nexuses database and newspaper web sites. The population for this research study included all editorials using the word " $9 / 11$ attacks", or “Al Qaeda”, or or "Osama bin Laden" in the headline or leading paragraph in the selected newspapers from 12September 2001 to 12 November 2001. This time period was chosen because it was close to 9/11 incident. And for two months the newspapers particularly discussed 9/11 attacks. Later on they started discussion on war on terror. The entire editorial including title, headline, body text and theme was taken as unit of analysis. The editorial was chosen for the study because editorials gave impression regarding the political affiliation of the newspaper and depicted the newspaper policy.

\section{Data analysis technique}

By applying thematic analysis the researcher investigated how Pakistani and British press framed the 9/11 attacks. For analyzing the content from newspapers, the study employed Inductive and deductive thematic analysis. The editorials of Pakistani British newspapers were chosen as the unit of analysisThe researcher started to analyze data based on the prior categories derived from previous literature but during analysis new themes and categorizes emerged from data. In this study grounded theory data analysis technique was used. For this reason, three types of coding was utilized: open coding, 
axial coding and selective coding [41]. Open coding involved labeling and classifying the phenomenon that was pointed by the data. Coding did not bring descriptions of the different aspects of data but it captured its meanings [42]. Axial coding: during this process the data was analyzed again by making associations between categories and its subcategories. The analysis explained the phenomenon implanted in the data. Selective coding integrated the categories to a structure or theoretical framework. Based on the following method data from British and Pakistani editorials was analyzed. For this purpose the researcher used NVIVO 10. The data indicated various categories which were classified as positive, neutral or negative themes. At the last stage, the researcher found out core categories from the data. These core categories depicted findings of the study.

\section{Findings}

The findings of the research were discussed in two sections. First it discussed British perspective, later on Pakistani perspective on $9 / 11$ attacks.

\section{Framing of 9/11 by British press}

In this section, the editorial coverage of The Guardian and the Independent were analysed. After the September 11 attacks, the British newspapers gave immense coverage to the issues related to terrorist attacks in the US, incidents of terrorism, US campaign against terrorism and the Al Qaeda. From September 12, 2001 to 11 November 2001, the editorials from the Guardian and the Independent were analysed.

\begin{tabular}{|c|c|c|}
\hline \multicolumn{2}{|c|}{ Prominent themes of British press regarding 9/11 attacks } \\
\hline Negative themes & Neutral themes & Supportive themes \\
\hline Pre September 11 warnings & $\begin{array}{c}\text { Responsible approach required by } \\
\text { British government }\end{array}$ & $\begin{array}{c}\text { Sympathies with America on 9/11 } \\
\text { tragedy }\end{array}$ \\
\hline Relating 9/11 incident to Iraq crisis & & \\
\hline Criticism on Bush's post 9/11 policies & & \\
\hline
\end{tabular}

By examining the editorials, it was observed that after the attacks, the British press mostly framed the tragedy in a neutral way. It sympathized with the Americans but it expressed certain concerns over US policies regarding combating terrorism. Particularly, The Guardian adopted a more neutral stance than The Independent on the incident of 9/11. In The Guardian, $60 \%$ references of the editorials indicated a neutral stance and $35 \%$ of the references framed the attacks negatively. On the other hand, $42 \%$ references in the Independent commented on the issue in a neutral stance but $57 \%$ were framed negatively by criticizing the military options.

After September 11 attacks, The Guardian and The Independent sympathized with the United States government and supported the British government stance over the 
tragedy. The press commented that government should support America but the support should not be at the expense of British national interests. However, it supported the American right of vengeance against the perpetrators of the attacks but it emphasized the need to take political measures to eradicate the roots of terrorism. The Guardian also advised Mr. Blair to support America in the outrages of 9/11 but it recommended the British government not to adopt a "shoulder to shoulder" approach towards American policies. Likewise, The Independent framed the $9 / 11$ attacks as a horrendous act of terrorism that killed hundreds of innocent people. It stated that:

"Terrible acts of barbarism against America, but still the response must be civilized" (The Independent, September 12, 2001, p. 3).

However, in the upcoming days The Guardian suggested to the British government many times to adopt a responsible approach for dealing with matters involving the September attacks. It cautioned the government not to follow every policy devised by the US government as it was contrary to British national interest. The Guardian also stressed that the 9/11 attacks could not be justified. It was a lethal act which killed many innocent people. Simultaneously, it was also pertinent to respond appropriately. It indicated that the response towards the attacks should be responsible; otherwise it could involve religious and cultural disputes. That was devastating for everyone.

It was noted that The Independent adopted a critical stance against the US post 9/11 polices. The Independent commented that among the Americans there was a strong sentiment to hit back at the terrorists. But it would be a vengeful act. America should bring the terrorists to justice. The culprits of the attacks should be punished but pursuing the policies of war against other countries would not be productive. It would not address the causes of terrorism yet it would increase hatred among the Muslims against the US:

"Terror in America: bring the murderers to justice, but tackle the causes of these outrages" (The Independent, September 14, 2001, p.3).

The Independent stressed that the British people were standing shoulder to shoulder with the Americans after the tragedy and wanted to avert such incidents in future. But President Bush's approach to these attacks was resentful and it could be counterproductive. It was commented that for combating terrorism America should reconsider its policy and consider eliminating the causes of terrorism. The British press deplored the 9/11 tragedy and framed these attacks as an awful tragedy 
that had an extensive and destructive impact but it was stressed to the British Government that it should adopt a balanced policy relating to the War on Terror and should try to remove the causes of terrorism. From the negative perspective the British press commented on the failure of US intelligence, pre-September 11 warnings of terrorism, Bush's post 9/11 polices and conduct of War on Terror.

Later on, in certain editorials, the Guardian criticized Bush's post 9/11 strategies. It argued that the US was pursuing the Republican domestic agenda after the 9/11 attacks and lacked international consensuses on certain issues. It further indicated that America was using the 9/11 attacks for its political gains. All US policies were framed in the context of the September attacks. All measures were justified in the name of patriotism and all opposition was suppressed for the sake of nationalism. It wrote that:

“... Mr. Bush, self-styled universal soldier for truth, will have to stop pretending that tragedy gave him a free hand to remake America and the world to fit his simplistic, narrow vision - or risk having voters and US allies end the pretence for him. For this is the delusion under which he labours. And a very dangerous delusion it is too" (The Guardian, January 31, 2002, p. 19).
Later on, President Bush's assertions to link 9/11 with President Saddam were highly criticized by the Independent. In July 2003, The Independent discussed a congressional report on September 11 and argued that there was no solid link between 9/11 and Iraq. It was the Bush administration that used the incident for pre-emptive war on Iraq. This report did not support any argument on Iraq's weapons of mass destructions (WMD).

It further argued that there were links between the 9/11 attacks and the Afghanistan regime but these links were also not very much clear. But the war in Afghanistan had brought severe consequences such as causalities and warlordism. Besides, Osama's agenda of perversions of Islam got strengthened in the minds of many fanatics in many other places. Overall, the stance of British press was neutral towards 9/11 attacks. It sympathised with America and condemned attacks. But it suggested its government not to provide shoulder to shoulder support to the US in its war on terror.

\section{Framing of 9/11 by Pakistani press}

By investigating the editorial coverage of Pakistani newspapers, it could be stated that the coverage was dominated by a negative stance. From the 9/11 attacks in the United States to the wars in Afghanistan and Iraq, the newspapers were against the United States' actions. 
However, after the 9/11 attacks, the

Pakistani press commented that it was the heinous acts of terrorism that should be condemned worldwide. The attacks on the twin towers caused great loss to human life and property. The aggression against humanity could not be justified.

\begin{tabular}{|c|c|c|}
\hline \multicolumn{2}{|c|}{ Prominent themes of Pakistani press regarding 9/11 attacks } \\
\hline Neutral themes & Negative themes & Supportive themes \\
\hline $\begin{array}{c}\text { World support to 9/11 attacks } \\
\text { 9/11incident as heinous act of } \\
\text { terrorism }\end{array}$ & Negative public opinion in Pakistan & $\begin{array}{c}\text { Need to determine the proper } \\
\text { identity of 9/11 perpetuators }\end{array}$ \\
\hline & $\begin{array}{c}\text { Hate crimes against Muslims after } \\
9 / 11\end{array}$ & \\
\hline & Criticism on post 9/11 policies of the \\
US
\end{tabular}

Initially, the Pakistan press discussed world support for the United States after the 9/11 attacks but later on Pakistani newspapers criticized the post $9 / 11$ policies of the US, hate crimes in the US, evidence against Osama and effects on economy. In November 2001, The Dawn stated that soon after the 9/11 attacks the Muslim countries gave warm support to War on Terror. America was able to gather world coalition against terrorism and Al Qaeda. The Muslim countries such as Saudi Arabia, Turkey and Egypt had offered their assistance to fight against Al Qaeda and capture Osama Bin Laden who was declared as the prime suspect for $9 / 11$ attacks by the United States. It was argued if America extended the War on Terror to other countries; it would be difficult for the Muslim states to support the War on Terror in the longer run. From the perspective of negative framing, The Nation argued that the Bush administration had madly started its campaign against the culprits of $9 / 11$ without properly determining the identity of 9/11 terrorists. The War on Terror caused many casualities and destruction. It was very important to establish the identity of the terrorists. America was a responsible country; it should not blindly pursue its war objectives. It was not confirmed yet whether Osama was responsible for the 9/11 but the way the American media and high officials had started campaigning against him had caused suspicion. The United States must consider the reaction of the Muslims against the attacks in Afghanistan that would be different from simple condemning of the $9 / 11$ attacks. It should be understood that the United States' action could be misperceived by the Muslim world. Likewise public opinion in Pakistan was not supportive of any action against the Muslim country.

Moreover, The Dawn reported on the indiscriminate behaviour and hate crimes against the Muslim population in the United States after $9 / 11$ in some of its editorials during September 2001. On September 22, 2001, The Dawn reported 
that after the $9 / 11$ attacks, there were 300 incidents of hate crimes against Arabs, Asian nationals and those who look like Muslims in the United States. It had become difficult for Muslim females to wear the hijab. Even children had stopped going to school due to humiliation and fear. Many young Muslim men were harassed by the security agencies. In American society the Muslims had become the victims of 9/11. The Muslims were perceived as potential terrorists and were badly treated. It was suggested that the United States Government should take actions against the discriminating attitude of the people; it would affect the campaign against terrorism. Many editorials noted from The Dawn and The Nation that criticized US post 9/11 polices. On December 31, 2002 the Dawn commented that American actions after 9/11 had affected the world in two ways. First, it set a bad precedent for those states that used force by state-backed terrorists, for instance Hindutva in Indian Gujrat and Sharon in Palestine. They could kill people without any moral pressures. Secondly, these policies were imperialistic in nature, causing alienation in the entire world. Moreover, the Bush administration by using the doctrine of regime change wanted to install pro-American Governments in those countries that were strategically important for it.
The Nation commented that the 9/11 attacks had changed the world. The United States adopted the aggressive approach to tackle the menace of terrorism and the policies of reason and restraint were muted. The Bush administration did not address the causes of terrorism but rather enhanced them. It was suggested that there should be mutual dialogues among different cultures and communities and the United States should address the grievances of the Muslims.

"There is a need to initiate a 'civilization' dialogue based on mutual tolerance and respect if the planet is not to be ultimately blown to bits. The West must address the genuine grievances of the Muslims especially, as well as of adherents of other faiths, and also correct its rapacious economic policies which have divided the world into 'haves' and 'have-nots'. The tragic 9/11 should also be seen as an ultimate act of desperation against accumulated injustices. A policy of 'live and let live' needs to be adopted." (The Nation, September 11, 2002, p. 6)

Overall, it was noted that Pakistani newspapers employed negative themes in the framing of 9/11 attacks. They criticised US post 9/11 activities but theyalso condemned the attacks.

\section{DISCUSSION}


Pakistan and British newspapers gave enough coverage to the September 11 attacks. There were number of articles were written on this incident. The present article compared the coverage of Pakistan and British press on these attacks. It was observed that British press appeared to be more neutral and positive towards these attacks as compare to Pakistani press. The British press (The Guardian and The Independent) sympathised with America and condemn these attacks whereas Pakistan press (The Dawn and The Nation) also condemn the attacks but it was more focused to criticise post $9 / 11$ policies of the US. While discussing the $9 / 11$ attacks, Pakistani newspapers used more hard language, tone and expression than Britain newspapers. The newspapers from the both sides criticized America for its aggressive polices regarding Muslim countries but Pakistani newspapers expressed more anger and annoyances against America. Pakistani newspapers were focused on the consequences of $9 / 11$ attacks on the Muslim countries and especially for Pakistan.

In the perspective of neutral and positive framing, the British newspapers discussed the following themes such as sympathy with the US, condemnation of $9 / 11$ attacksand adoption of responsible approach by the British government to deal with the crisis. From negative perspective, the British newspapers criticised US post 9/11 polices, Bush's resentful approach and assertion of 9/11 attacks with Saddam Husain. However, by looking at Pakistani data, it was noted that negative themes dominated the coverage. Pakistani newspapers discussed the following themes criticism on US post 9/11 policies, hate crime against the Muslim population in the US, evidence against Osama Bin Laden, negative public opinion in Pakistan, criticism on war on terror and negative impact on world economy.

\section{CONCLUSIONS}

By looking at the data, it could be concluded that the press from both countries criticised 9/11 attacks and condemn the atrocity. But the Press from Pakistan and British depicted the incident with different perspectives. Pakistan press highlighted the impact of $9 / 11$ attacks on the Muslim countries and criticised war on terror which caused many causalities whereas British press gave sympathetic impression but advised its country to take responsible actions in response to these attacks.

\section{REFERENCES}

[1]Lansford, Tom, et al. America's War on Terror. farnham, surrey. Ashgate Publishing Group., 2009.

[2]Monahan, Brian A. The Shock of the News: Media Coverage and the Making of 9/11. New York UP, 2010. 
[3]Stempel, G., Hargrove, T. "Media Sources of Information and Attitudes about Terrorism." Communication and Terrorism: Public and Media Responses to $9 / 11$, edited by B. S. Greenberg, 2002, pp.17- 26, Cresskill, NJ: Hampton Press.

[4]Cohen, E. L., Ball-Rokeach, S. J., Jung, J., \& Kim, Y. C. "Civic actions after September 11th: A communication infrastructure perspective." Crisis Communications: Lessen from September $11^{\text {th }}$,edited byM. Noll, 2003, pp. 31-44, Lanham, MD: Rowman \&Littlefield Publishers, Inc.

[5]Bram, Jason., Orr, James., and Rapaport. "Measuring the Effects of the September 11 Attack on New York City." Economic policy review, Vol, 8, no. 2, 2002.

[6]Roberts, Bryan., "The Macroeconomic Impacts of the 9/11 Attack: Evidence from Real-Time Forecasting."Peace Economics, Peace Science, and Public Policy, 2009, vol. 15, no 2, 1-29.

[7]Nisbet M. "Media Coverage After the Attack: Reason and Deliberative Democracy Put to the Test." CSI, 2001.

[8]Zhang, Juyan. "Beyond anti-terrorism: Metaphors as message strategy of postSeptember-11 U.S. public diplomacy." Public Relations Review, vol. 33, no. 1, 2007, pp. 31-39.
[9]D, Snauwaert T. "The Bush Doctrine and Just War Theory." The Online Journal of Peace and Conflict Resolution, vol. 6, no. 1, 2004, pp. 121135.

[10]Bush W. "Remarks by the president in photo opportunity with the national security

team." Whitehouse.gov,12 Sept. 2001,w ww.whitehouse.gov/news/releases/200 1/09/20010912-4.

Accessed 12 Sept. 2001.

[11]Gamson, William A., and Andre Modigliani. "Media Discourse and Public Opinion on Nuclear Power: A Constructionist Approach." American Journal of Sociology, vol.95, no. 1, 1989, pp. 1-37.

[12]Cissel M. "Media framing: a comparative content analysis on mainstream and alternative news coverage of Occupy Wall Street." The Elon journal of undergraduate research in communication, vol. 3 , no. 1, 2012, pp. 67-77.

[13]Tuchman, Gaye. "Making News: A Study in the Construction of Reality." New York Free Press, 1978.

[14] Iyengar, Shanto. "Is Anyone Responsible? How television frames political issues." University of Chicago Press, 1991.

[15]Reese, Stephen D. "The Framing Project: A Bridging Model for Media 
Research Revisited." Journal of Communication, vol. 57, no. 1, 2007, pp. $148-154$.

[16] De vreese, and C. H. "News framing: Theory and typology." Identifying information and tenor in texts, vol. 13, no. 1, 2005, pp. 51-62.

[17] Gitlin, T. The whole world is watching: Mass media in the making and unmaking of the New Left. University of California press, 1980.

[18] Nelson, John S, and G R. Boynton. Video Rhetorics: Televised Advertising in American Politics. university of 1llinois press, 1997.

[19]Kinder, Donald R., and Lynn M. Sanders. "Mimicking Political Debate with Survey Questions: The Case of White Opinion on Affirmative Action for Blacks." Social Cognition, vol. 8, no. 1,1990, p.74.

[20]Entman, Robert M. "Symposium Framing U.S. Coverage of International News: Contrasts in Narratives of the KAL and Iran Air Incidents." Journal of Communication, vol. 41, no. 4, 1991 , p.7.

[21] Cappella, Joseph N, and Kathleen H. Jamieson. Spiral of Cynicism: The Press and the Public Good. Oxford UP, 1997, p. 39.

[22] Bateson, G. Steps to ecology of the mind. New York: Ballantine, 1972, p.186.
[23]Reese, Stephen D, et al. Framing Public Life: A Bridging Model for Media Research. Mahwah, NJ: Erlbaum., 2001.

[24]Amy, R. \& Barnett, B. "America under attack: CNN's verbal and visual framing of September $11^{\text {th }}$ "Media Representations of September $11^{\text {th }}$, edited by Steven C., Frank, B., \& Brown M., 2003, New York: Praeger, pp. 85-101.

[25] Barrett, Boyed. "Doubt Foreclosed: US Mainstream Media and the Attacks of September 2001." Terrorism, Globalization and Mass Communication, edited by D. Demer, 2003, pp.3-33, Spokane, WA: Marquette Books.

[26]Kumar, Deepa. "Media, War, and Propaganda: Strategies of Information Management During the 2003 Iraq War." Communication and Critical/Cultural Studies, vol. 3, no. 1,2006 , pp. 48-69.

[27]Miller, David. Tell Me Lies: Propaganda and Media Distortion in the Attack on Iraq. Pluto, 2004.

[28]Schudson, Michael. "What's unusual about covering politics as usual." Journalism after September 11. New York: Routledge, pp. 36-47.

[29]Reynolds, A., \& Barnett, B. “America under attack: CNN's verbal and visual framing of September 11" Media 
Representations of September $11^{\text {th }}$ edited byS. Chermak, F. Bailey \& M. Brown, 2003, pp. 85-102, New York: Praeger.

[30]Haes, J.W. H. "September 11 in Germany and the United States: Reporting, Reception, and Interpretation". Crisis Communications: Lessons from September 11, edited by A.M. Noll, 2003, MD: Rowman \& Littlefield.

[31]Clausen, Lisbeth. "Global News Communication Strategies 9.11.2002." Nordicom Review, vol. 24, no. 2, 2003, pp. 105-16.

[32] Gao, et al. "Chinese print media coverage of 9/11 since 2001." Journal of Media Sociology, vol. 2, no. 4, 2010, pp. 186-205.

[33] McNair B. "UK Media Coverage of September 11." Journal of media sociology,, vol. 2, no. 4, 2010, pp. 2937.

[34] Kennedy, p. "The genie is out of the bottle. "Theindependent,http.//agument .indepdendent.co.uk/commentators/stor y.jsp? story - 94233. Accessed 16 Sept. 2001.

[35] M, Marron B. "Elite British and Irish Newspapers Reflect Ideology In Framing The 9/11 Catastroph." Journal of Media Sociology, vol. 2, no. 4, 2010, pp. 38-50.
[36]Ahmad, I. M., Mahsud, N. M., \& Ishtiaq, T. "Pakistani press and war against terrorism in democratic era." Berkeley Journal of Social Science, vol. 5 no $1,2011$.

[37]Creswell, John W. "Research Design: Qualitative and Quantitative Approaches." sage, 1994.

[38]Popping, Roel. "Computer-assisted Text Analysis." sage, 2000.

[39]Rice P., and Ezzy D. Qualitative Research Methods: a Health Focus. Oxford UP, 1999.

[40]Boyatzis, R.E. "Transforming Qualitative Information: Thematic Analysis and Code Development. "1998, London: Sage Publications.

[41]Corbin, Juliet, and Anselm Strauss. "Basics of Qualitative Research: Techniques Procedures for Developing Grounded Theory (2nd ed.)." Thousand Oaks: Sage, 1998. www.csicop.org/specialarticles/show/ media_coverage_after_the_attack_reas on_and_deliberative_democracy_put_t o_th/. Accessed 8 Feb. 2012.

[42] Sharmaz, Kathy. "Constructing Grounded Theory. A practical guide through qualitative analysis." The SAGE Handbook of Social Research Methods, 2006. 